\title{
EDITORIAL
}

Neste número da Revista Brasileira de Educação Profissional e Tecnológica reunimos artigos que têm como temática a produção do conhecimento em Educação Profissional.

No Brasil, o campo da Educação Profissional (EP) foi se constituindo a partir de estudos que remetiam as variáveis que cortam a EP como modalidade de ensino, mas que na última década sofreu expressivo aumento na produção e difusão do conhecimento.

Esse é um campo de investigação que ainda é recente no Brasil. Mas, ganha contornos com eventos como esse, o Colóquio Nacional - A produção do conhecimento em Educação Profissional, com o aumento de publicações em livros e revistas sobre EP, e a criação de Programas de PósGraduação, como o de Educação Profissional do IFRN.

Assim, esse número apresenta artigos que (re)pensam a constituição do campo da EP, a exemplo dos trabalhos A produção do conhecimento sobre educação profissional e Estado do conhecimento da Educação Profissional e Tecnológica na pós-graduação, stricto sensu, em Serviço Social, da região Centro-oeste.

Nessa mesma perspectiva, ainda compõe esse número os artigos Formação de professores para a educação profissional e tecnológica a distância da rede federal de educação brasileira: análise das produções acadêmicas e Análise da produção científica nos cursos técnico de nível médio do IFRN Campus Pau dos Ferros: estudo de caso das turmas 2012.1 (2012-2015).

Esperamos com esse número instigar novos olhares sobre a produção do conhecimento sobre Educação Profissional no Brasil e, dessa maneira, colaborar com a (re)configuração desse campo.

\section{À leitura!}

Natal-RN, 16 de dezembro de 2015

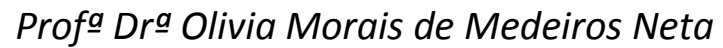
Prof. Dr. Dante Henrique Moura 